\title{
Glacier dynamics in the Western Italian Alps: a minimal model approach
}

D. Peano ${ }^{1,{ }^{*}}$, M. Chiarle ${ }^{1}$, and J. von Hardenberg ${ }^{2}$

${ }^{1}$ IRPI-CNR, Strada delle Cacce 73, 10135 Torino, Italy

${ }^{2}$ ISAC-CNR, Corso Fiume 4, 10133 Torino, Italy

"now at: University Ca' Foscari, Venezia, Italy and CMCC, Bologna, Italy

Received: 17 January 2014 - Accepted: 14 February 2014 - Published: 6 March 2014

Correspondence to: D. Peano (daniele.peano@irpi.cnr.it)

Published by Copernicus Publications on behalf of the European Geosciences Union.

Glacier dynamics in the Western Italian Alps

D. Peano et al.

\section{Title Page}

\section{Full Screen / Esc}

Printer-friendly Version

Interactive Discussion 


\section{Abstract}

We study the response of a set of glaciers in the Western Italian Alps to climate variations using the minimal glacier modeling approach, first introduced by Oerlemans. The mathematical models are forced over the period 1959-2009, using temperature

5 and precipitation recorded by a dense network of meteorological stations and we find a good match between the observed and modeled glacier length dynamics. Forcing the model with future projections from a state-of-the-art global climate model in the RCP 4.5 and RCP 8.5 scenarios, we obtain a first estimate for the "expiration date" of these glaciers.

\section{Introduction}

High mountain regions present an heterogeneous landscape, which includes glaciers, rocks, debris, streams and lakes, and rich ecosystems. Climatic variations in mountain areas can lead to important environmental hazards such as landslides and floods (Deline et al., 2012; Chiarle and Mortara, 2008; Stoffel and Huggel, 2012) or changes in water availability and quality (Braun et al., 2000; Viviroli et al., 2011; Beniston, 2012). At the same time mountain environments respond strongly to climate change and different aspects of mountain regions respond to ongoing climate fluctuations; for example, the air temperature increase in the 20th century in the Alps has been twice the average increase on a global scale (Brunetti et al., 2006). Alpine glaciers in particular present a strong and rapid reaction to climate oscillations (Nesje and Dahl, 2000; Bonanno et al., 2013), and they can be used as indicators of the "health" of the local mountain environments (Kääb et al., 2007).

The Alpine region is characterized by an abundance of glaciers (Zemp et al., 2008), but only few of them are well studied. The time series of frontal variations are the most frequently available data. Many factors control the response of glaciers to climate forcing: volume, shape, aspect, slope, and elevation are among the most important
Glacier dynamics in the Western Italian Alps

D. Peano et al.

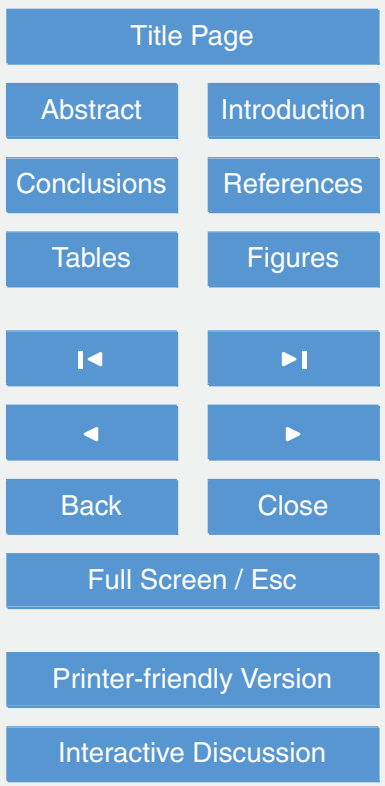


ones. According to the combination of these and other factors, some glaciers are more sensitive to variations of winter precipitation, while others are more sensitive to summer temperatures. The time and mode of response to climatic oscillations vary from one glacier to another, and even between different parts of the same glacier (Calmanti 5 et al., 2007).

Different models have been developed to understand and study the evolution of glaciers, starting from measured time series, ranging from linear and zero dimensional models, such as the "minimal model" presented by Oerlemans (Oerlemans, 2011; Oerlemans et al., 2011), to one or higher dimensional models, such as flowline model and 10 full thermo-mechanical models (e.g., Oerlemans, 1997; Pattyn, 2002; Zwinger et al., 2007). Simple models require few input data and limited computing time and for these reasons they are suitable for performing a first estimate of the sensitivity of a high number of glaciers to changes in climate parameters. When forced with future climate scenarios, they can provide an order-of-magnitude estimation for the glaciers "expira15 tion date" (Bonanno et al., 2013).

With this aim, in this work we adapt and test one version of a minimal glacier model developed by Oerlemans (2011) applying it to a set of glaciers of the Western Italian Alps. The paper presents the available data for the region of our interest in Sect. 2, and describes the method applied in Sect. 3. The results are reported in Sect. 4, while

Sect. 5 displays the future projection for the considered glaciers. Final remarks are provided in Sect. 6 . The physical properties of the studied glaciers are reported in Appendix A.

\section{Available data}

\subsection{Study area}

We focus on the Western Italian Alps, which host some of the most important and best preserved glacierized areas of Italy. The most recent statistics on Italian glaciers
TCD

$8,1479-1516,2014$

Glacier dynamics in the Western Italian Alps

D. Peano et al.

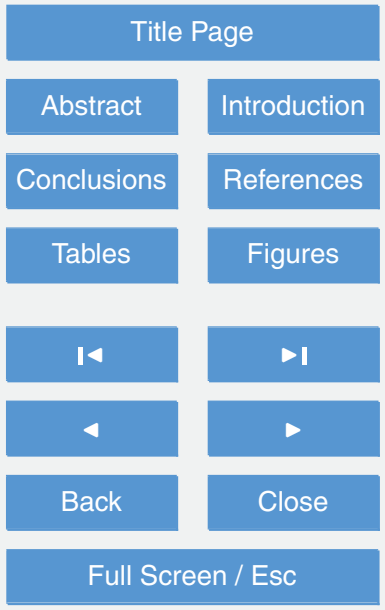

Printer-friendly Version

Interactive Discussion 
are based on an inventory prepared in 1989, which identified 807 glaciers (Ajassa et al., 1997). Most of them have been classified as small or very small: $101(13 \%)$ have a surface smaller than $0.05 \mathrm{~km}^{2}$, and 591 of them $(73 \%)$ have a surface ranging between 0.05 to $1 \mathrm{~km}^{2}$. The inventory identified 308 glaciers in the Western Italian Alps 5 (38\% of the total), accounting for $42 \%$ of the total glacierized area in the Italian Alps.

The locations of the glaciers considered in this work are shown in Fig. 1. These glaciers have been selected based on the availability and reliability of glaciological data, and they represent glaciers with different characteristics in terms of size, shape and physical properties.

10 The Ciardoney and Grand Etrèt Glaciers (Gran Paradiso Massif) have the longest and most complete series of mass balance measurements and they allow for running the model using directly measured mass balance data. Nine additional glaciers, for which mass balance information is not available (Basei, Bessanese, Capra, Lys, Moncorvè, Mulinet Nord, Mulinet Sud, Prè de Bar and Valtournanche), are modeled assuming an empirical relationship between mass balance and climate variables. These latter glaciers were selected because a reliable time series of length fluctuation data was available for each of them. The main properties of the glaciers considered here are listed in Appendix A and in Table 1.

\subsection{Glaciological data}

20 We use glacier length measurements by the Italian Glaciological Committee, which has performed and published this type of measurements since the beginning of the past century (http://www.glaciologia.it/). Mass balance and Equilibrium Line Altitude (ELA) measurements for the Ciardoney Glacier have been annually performed by the Italian Meteorological Society (SMI; http://www.nimbus.it). The mass balance of the Grand

25 Etrèt Glacier has been measured by the personnel of the Gran Paradiso National Park (GPNP; http://www.pngp.it/).

Glacier dynamics in the Western Italian Alps

D. Peano et al.

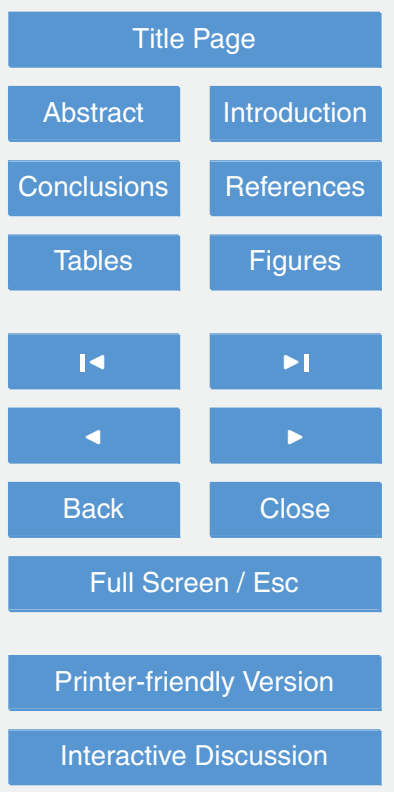


Series of measured length variations, ELA position and mass balance data are available from 1971 to 2009 for the Ciardoney glacier and from 1997 to 2009 for the Grand Etrèt glacier, as shown in Fig. 2.

Values of geometrical parameters, such as reference length, glacier minimum and 5 maximum height, have been obtained in a Geographic Information System (GIS) environment from aerial images released by the Italian Ministry of Environment, taken during flights in 2006 and 2000 over the Italian territory (http://www.pcn.minambiente. it/GN), and are summarized in Table 1 and in Appendix A.

\subsection{Climate data}

10 Temperature and precipitation recorded by a network of meteorological stations are made available by the Regional Agency for Environmental Protection of Piedmont, Italy (ARPA; http://www.arpa.piemonte.it). In this work we use seasonal averages of daily values, regridded onto a regular grid $\left(0.125^{\circ} \times 0.125^{\circ}\right)$ using an Optimal Interpolation (OI) technique (Uboldi et al., 2008), for the Piedmont and Valle d'Aosta regions in Northwestern Italy in the period 1959-2009. In the analysis, we consider seasonal averages of precipitation during the accumulation period (from October to May) and temperature during the ablation season (from June to September): this choice is supported by the outcomes of a study carried out by Bonanno et al. (2013) on glaciers of the same area by mean of a stepwise regression technique, which showed that the conditions. We indicate these two seasonal averages as "October-May precipitation", and "June-September temperature" respectively. The seasonal averages have been standardized by removing, for each grid point, the climatological mean in the period

1971-2000 and dividing by the standard deviation in the same period.

Precipitation and surface temperature data from the EC-Earth Global Climate Model (GCM) in the period 1959-2100 were used to force the models for application to future projections. EC-Earth (Hazeleger et al., 2012) is a state-of-the-art global climate

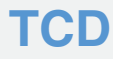

$8,1479-1516,2014$

Glacier dynamics in the Western Italian Alps

D. Peano et al.

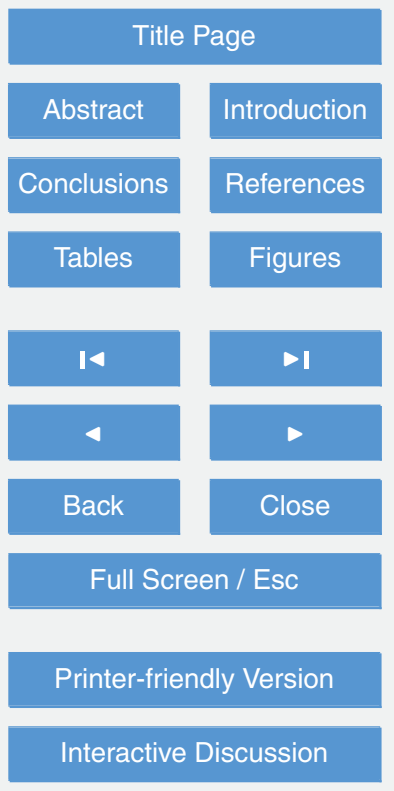


model developed by a european consortium, which includes the Integrated Forecast System atmospheric model by European Centre for Medium-range Weather Forecast (ECMWF) for the atmosphere, the Nucleus for European Modelling of the Ocean (NEMO) for the ocean component and the land-surface modulus $\mathrm{H}$-Tessel and the 5 Louvain-la-neuve sea-Ice Model (LIM). The scenarios used here are Representative Concentration Pathway (RCP) projection RCP 4.5 and RCP 8.5 prepared with ECEarth v. 2.3 for the Climate Model Intercomparison Project (CMIP5) archives, using the model with atmospheric resolution $1.125^{\circ}$ and 62 levels. An ensemble of seven different realizations of monthly averaged values was available for the RCP 4.5 scenario and an 10 ensemble of nine realizations was used for the RCP 8.5 scenario. All ensemble members were obtained using different initial conditions at the beginning of the historical period (in 1850).

\section{Minimal glacier models}

Minimal glacier models assume a simplified glacial geometry and the time-evolution 15 of glacier length is computed from a continuity equation for the whole glacier, typically using an instantaneous relationship between glacier length and depth. As such, they cannot describe the propagation of kinematic waves or depth variations along the glacier. Since these models include only a few parameters, they are particularly useful for the study of the interaction between glaciers and climate, especially when limited information on the glacier characteristics is available. In the following, we use a very simple model introduced by Oerlemans (Oerlemans, 2001, 2011; Oerlemans et al., 2011), which considers a glacier of uniform width resting on a bed with constant slope, and with a constant mass balance gradient along the glacier.

This idealized glacier geometry is illustrated in Figs. 3 and 4. Ice thickness is as25 sumed constant along the entire glacier and set equal to a mean ice thickness, $H(t)$, which is only a function of time $t$. The total glacier volume is $V(t)=W H(t) L(t)$, where $L(t)$ is the time-varying glacier length and $W$ is the (fixed) glacier width. More complex

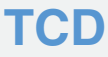

8, 1479-1516, 2014

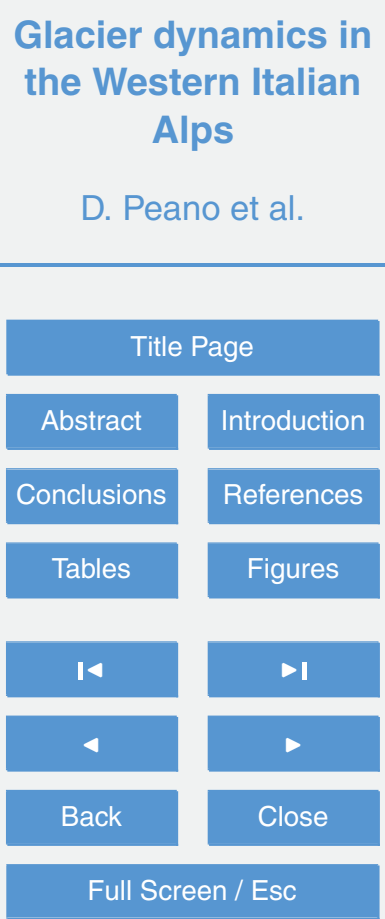

Printer-friendly Version

Interactive Discussion 
geometries could also be used; for example, one might consider a glacier with varying width or with varying bed slope.

The assumption of perfect plasticity is used to retrieve a relationship between the mean ice thickness value $H$ and the glacier length $L$ (Oerlemans, 2011):

${ }_{5} H=\frac{\alpha_{\mathrm{m}} L^{1 / 2}}{1+v S}$

where $\alpha_{\mathrm{m}}$ and $v$ are constants and $s$ is the mean bed slope. The two constants values are taken from Oerlemans (2011) and then tuned to fit the observed glacier length values, obtaining, as best case, the values reported in Table 1.

The two main sources of volume change for a glacier are the surface balance, $B_{\mathrm{s}}$, 10 and, in the presence of a frontal water basin, a calving flux (Oerlemans, 2011). Since here we focus on Alpine glaciers, where frontal water basins occur only in few specific cases, we ignore the calving flux in the following.

The total mass balance of the glacier, $B_{\mathrm{s}}$, can be estimated according to ELA oscillations, as suggested by Oerlemans $(2011,2010)$. Alternatively, when direct mass 15 balance measurements are available, one can use the expression $B_{\mathrm{s}}=\dot{b} W L$, where $\dot{b}$ is the surface average of the measured net annual mass gains or losses at specific points on the glacier.

The temporal variation of the total glacier volume can thus be written as

$$
\begin{aligned}
\frac{\mathrm{d} V}{\mathrm{~d} t} & =\frac{\mathrm{d}}{\mathrm{d} t}(W H L) \\
& =H W \frac{\mathrm{d} L}{\mathrm{~d} t}+H L \frac{\mathrm{d} W}{\mathrm{~d} t}+W L \frac{\mathrm{d} H}{\mathrm{~d} t} \\
& =B_{\mathrm{s}}=\dot{b} W L
\end{aligned}
$$

where $H$ is given by Eq. (1) and its time derivative is

$$
\frac{\mathrm{d} H}{\mathrm{~d} t}=\frac{\alpha_{\mathrm{m}}}{2(1+v s)} L^{-1 / 2} \frac{\mathrm{d} L}{\mathrm{~d} t} \text {. }
$$

Glacier dynamics in the Western Italian Alps

D. Peano et al.

Title Page

\section{Full Screen / Esc}

Printer-friendly Version

Interactive Discussion 


$$
\frac{\mathrm{d} L}{\mathrm{~d} t}=\frac{\dot{b} L}{\frac{3 \alpha_{\mathrm{m}}}{2(1+v s)} L^{1 / 2}} .
$$

In the following, $B_{\mathrm{s}}$ is obtained from direct mass balance measurements, and the glacier length variations estimated by the model are compared with data on glacier 5 snout fluctuations. Since mass balance data are usually available on shorter time spans than snout fluctuation measurements, we extend the mass balance information by determining an empirical relationship between mass balance and climatic variables such as June-September temperature and October-May precipitation, determined from the years when the mass balance is measured. Such an empirical relationship is then used to estimate the mass balance from climatic variables, for the years when direct balance data are not available and for future climatic conditions. A similar approach was used by Calmanti et al. (2007) to link glacier length fluctuations to climatic variability in previous years; here, we use a direct, same-year relationship between glacier mass balance and climate. This approximation is justified thanks to the small size of the considered glaciers which allows to assume an instantaneously response to climate forcing. The glacier response is produced by the integration of the dynamical model Eq. (4). This equation is advanced in time with a simple forward Euler scheme, which provides accurate solutions since glacier length fluctuations are strongly damped.

\section{Modeling results}

\subsection{Ciardoney and Grand Etrèt glaciers}

The Ciardoney and the Grand Etrèt glaciers have both measured mass balance series, covering the period 1992-2009 (Mercalli and Berro, 2005) and 2000-2009 (provided by GPNP) respectively (Fig. $2 a$ and $b$ ), and a measured series of temperature and
8, 1479-1516, 2014

Glacier dynamics in the Western Italian Alps

D. Peano et al.

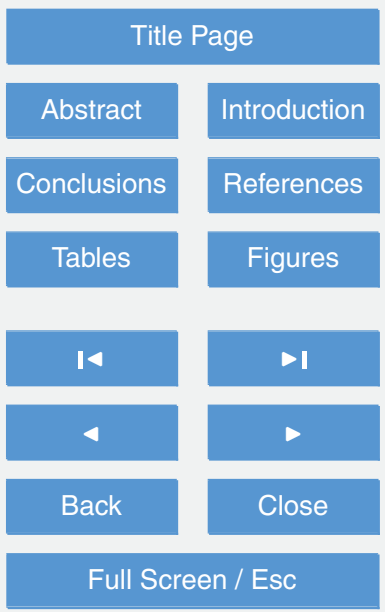

Printer-friendly Version

Interactive Discussion 
precipitation, ranging from 1959 to 2009 (provided by ARPA), so that a relation between these variables can be obtained directly.

The mass balance of glaciers can be determined as the difference between accumulation and ablation usually calculated on an annual basis. The accumulation depends 5 mainly on October-May precipitation, which usually occurs as snow, while the ablation depends on June-September temperature as suggested by Calmanti et al. (2007).

We considered the standardized temperature and precipitation time series which refer to the two boxes of ARPA's Optimal Interpolation grid in which the two glaciers are located. These two climatic variables have been related to the measured mass 10 balance series using a bivariate fit:

$\dot{b}_{i}=a T_{\mathrm{s}, i}+b P_{\mathrm{w}, i}+c$

where $\dot{b}_{i}$ represents the superficial mass loss or gain for the $i$ th year, $T_{\mathrm{s}, i}$ is the standardized June-September temperature and $P_{\mathrm{w}, i}$ is the standardized October-May precipitation for the same year. These values are standardized using the method described 15 in Sect. 2.3. The three parameters represent the weight of the influence of JuneSeptember temperature $(a)$, October-May precipitation $(b)$ and other features $(c)$ on the mass balance.

A fit between the measured mass balance and the climate data over the years in which the mass balance observations are available provides $a=-0.48$ [mweyear ${ }^{-1}$ ], 20 $b=0.63$ [mweyear $^{-1}$ ],$c=-0.85$ [mweyear $^{-1}$ ] for the Ciardoney Glacier and $a=$ $0.06\left[\right.$ mweyear $^{-1}$ ],$b=0.67\left[\right.$ mweyear $^{-1}$ ],$c=-0.97\left[\right.$ mweyear $^{-1}$ ] for the Grand Etrèt Glacier. Here the mass balance is measured in meters of water equivalent (mwe) per year. For the Grand Etrèt Glacier we find a negligible dependence on JuneSeptember temperature. The measured mass balance can thus be related to stan25 dard October-May precipitation alone, setting $a=0$ and finding $b=0.66\left[\right.$ mweyear $\left.^{-1}\right]$, $c=-0.96\left[\right.$ mweyear $\left.^{-1}\right]$.

Equation (5) relates the observed surface mass balance to temperature and precipitation values: in this way, climatic oscillations are introduced in the model as external

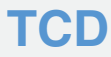

8, 1479-1516, 2014

Glacier dynamics in the Western Italian Alps

D. Peano et al.

Title Page

Abstract Introduction

Conclusions References

Tables

Figures

14

DI

4

Back

Close

Full Screen / Esc

Printer-friendly Version

Interactive Discussion 
forcing through $\dot{b}$ and we find a relationship which will allow us to reconstruct mass balance also in years when it was not measured and to project future mass balance also in climate scenarios.

We use the mass balance reconstructed using Eq. (5) to force and integrate the min5 imal model Eq. (4). Figure $5 \mathrm{a}$ and $\mathrm{b}$ show that over the full period over which length measurements are available we find a good match between the length dynamics determined from the mass balance reconstructed from the climate variables through Eq. (5) (continous line) with the observed length fluctuations (circles). Since the coefficients in Eq. (5) have been determined only in the period in which the mass balance measure10 ments were available we can consider the other years as an example of out-of-sample prediction.

The sensitivity of our approach (mass balance estimate plus glacier model) has been tested using two different methods. The first method considers the difference between the mass balance values obtained from Eq. (5) and the measured values as residuals 15 due to a background noise. The standard deviation of this residual, $\sigma_{\mathrm{r}}$, is introduced in Eq. (5) multiplied by a Gaussian white noise term, $w_{i}$ :

$\dot{b}_{i}=a T_{\mathrm{s}, i}+b P_{\mathrm{w}, i}+c+\sigma_{\mathrm{r}} w_{i}$

We compute 100 independent realizations of the integrated timeseries using independent random forcing and from these we determine a $90 \%$ confidence region for the model's results, shown as a light gray range in Fig. $5 a$ and b.

The other method consists in sub-sampling the series of measured mass balance, standard precipitation and standard temperature obtaining subsamples with half the original length (18 values for the Ciardoney glacier and 10 values for the Grand Etrèt), from which the sensitivity to the fit parameters can be evaluated. Here 1000 series are 25 created by sub-sampling the original one. The $90 \%$ confidence bands obtained with this method are shown in Fig. $5 \mathrm{a}$ and $\mathrm{b}$ with dark gray bands.

This second error band is wider than the band obtained with the first method. This points out the sensitivity of the model to the fit parameters $(a, b, c)$ used in Eq. (5),

Glacier dynamics in the Western Italian Alps

D. Peano et al.

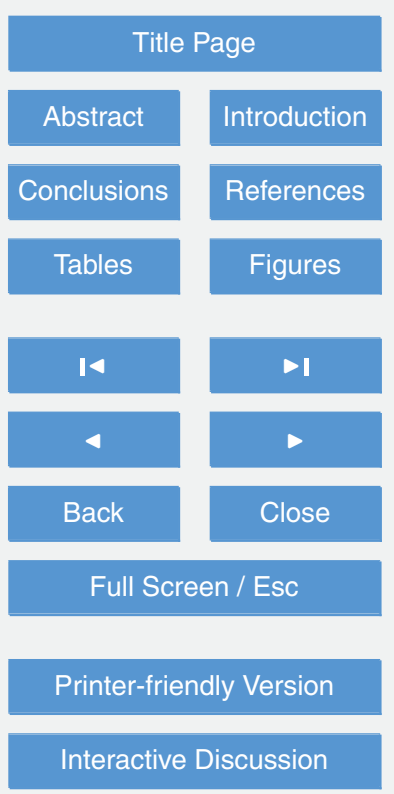


since their variation influences the model results more than the presence of an internal noise.

We observe that the Ciardoney and the Grand Etret glaciers are only a few kilometers apart, and it can thus be assumed that they are exposed to similar climatic 5 conditions: nevertheless, model outcomes show very different relations between mass balance and climatic parameters for the two glaciers. This finding is in agreement with outcomes from other alpine areas (e.g. Kuhn, 1985) and it highlights the importance to take into account the spatial and temporal diversity of mountain glaciers when analyzing their response to climate change (Winkler et al., 2010). In addition both glaciers, 10 but in particular the Grand Etret Glacier, show a stronger dependency of mass balance on precipitation rather than on temperature, challenging previous studies which assess that Alpine glaciers, at least in recent decades, are more sensitive to changes in temperature than precipitation (Thibert et al., 2013; Steiner et al., 2008). According to the latter reference, sensitivity to precipitation rather than temperature is a characteristic of maritime glaciers in contrast to continental glaciers. On the other side, it has to be mentioned that some authors attribute the onset of the post-LIA retreat and subsequent periods of re-advances in the European Alps to changes in winter precipitation rather than on temperature (Vincent et al., 2005). The stronger dependence of the Grand Etret Glacier to precipitation in comparison to the Ciardoney Glacier can likely be explained by the different aspect of the two glaciers, facing north and east respectively: the two glaciers, in fact, have very similar surface, elevation and form. In any case, it should be emphasized that in both cases, for the ablation part, a major role is played by parameter $c$, which accounts for factors other than climate that condition glacier mass balance.

\subsection{Glaciers without measured mass balance}

The model presented in this work needs measured values of mass balance to attain a relation between mass balance and climatic fluctuations. Unfortunately, mass balance data are available only for a small number of glaciers, while measures of length

Glacier dynamics in the Western Italian Alps

D. Peano et al.

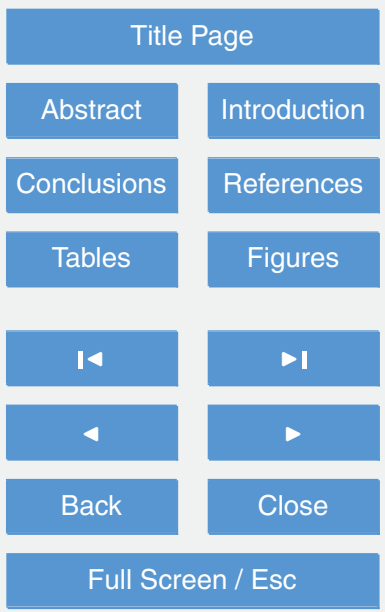

Printer-friendly Version

Interactive Discussion 
variations have been collected for the last one hundred years for many of the Italian glaciers. Considered also that a general relation between mass balance and climatic factors cannot be easily found, as shown by the cases of the Ciardoney and Grand Etrèt glaciers, a simple empirical mass balance reconstruction is required.

5 Assuming that the mass balance is related to the climate variables with the same Eq. (5) used above, we seek the combination of $a, b, c$ that minimizes the root mean square (RMS) difference between the measured glacier length variations and the modeled ones when the minimal model Eq. (4) is applied. In particular we minimize

$D(a, b, c)=\sqrt{\frac{\sum\left(L-L_{\mathrm{m}}\right)^{2}}{n}}$

10 where $L_{m}$ are the measured lengths and $L$ are those obtained from the model. The sum is over the years present in both series, and $n$ is the number of the common years. For the climate variables we use the standardized June-September temperature and October-May precipitation in the box of the ARPA's Optimal Interpolation grid which contains the glacier. This minimization is achieved from a forward computation of many different parameter combinations of $a, b$ and $c$.

As an initial validation, this procedure has been applied to the Ciardoney and Grand Etrèt glaciers, for which a direct relation between mass balance and climatic variables has already been determined in the previous section. Table 2 compares the best parameter values for Ciardoney and Grand Etrèt obtained using the direct method and the minimization method. The parameters values of the Ciardoney Glacier displayed in Table 2 are similar in the two cases, while the parameters values of the Grand Etrèt Glacier show a similar behavior except for $b$, which displays a larger influence on the mass balance in the measured case compared to the modeled one.

We applied the method to nine glaciers of the north-western Italian Alps without 25 an observed mass balance, namely Basei, Bessanese, Capra, Lys, Moncorvè, Mulinet Nord, Mulinet Sud, Prè de Bar and Valtournanche (see Fig. 1). The geometry
TCD

$8,1479-1516,2014$

Glacier dynamics in the Western Italian Alps

D. Peano et al.

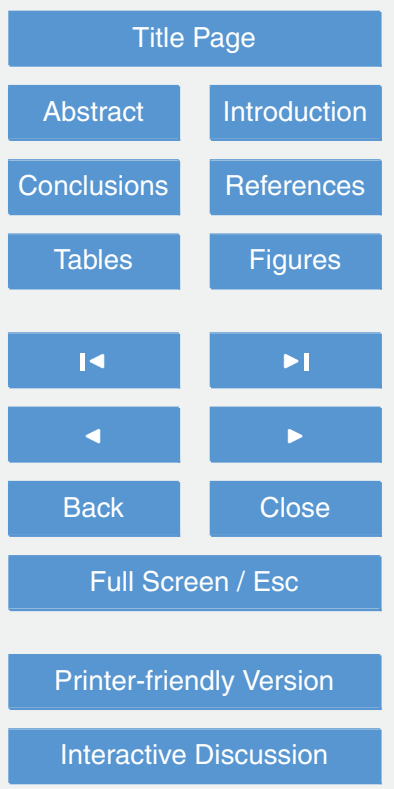


information required by the model for these glaciers is described in Table 1 . The parameter values resulting from the minimization procedure are listed in Table 3.

Figure 6 reports the evolution of glacier lengths obtained from the model using parameter values for the mass balance which minimize the root mean square distance 5 to the observed lengths (Eq. 7). In order to gauge the sensitivity to the parameter estimates in Table 3, we repeated the minimization process sampling randomly a subset of years using only half of the available years. We repeated this process 100 times, to obtain $90 \%$ confidence regions, which are reported as light-gray shaded areas in the figure.

10 Each of the glaciers considered here has different characteristics, such as shape, aspect, volume, etc., which can influence the accuracy of the obtained results (see Appendix A). The accuracy of the results can be represented using the RMS difference between the measured series of length variations and the modeled one obtained using the parameter values in Tables 2 and 3. These tables highlight that the model that we use works better with small glaciers, with a length ranging from few hundreds of meters to about $2000 \mathrm{~m}$, while the RMS difference is very large for the two largest glaciers, the Prè de Bar and Lys glaciers. The value of the root mean square difference in the case of the Prè de Bar Glacier is much higher than any other one, suggesting a glacier behavior strongly conditioned by factors other than glacier dimensions. This result points out that larger glaciers need a more complex model, able to better represent their shape and evolution, since the minimal model presented here is not capable to reproduce satisfactorily their dynamics.

The glaciers considered in this work, in general, show a strong retreat in the last decades, which has also been observed in other Alpine regions (e.g. Diolaiuti et al., 2012; Paul et al., 2004). If we analyze in detail the model results, the nine glaciers can be divided into three groups:

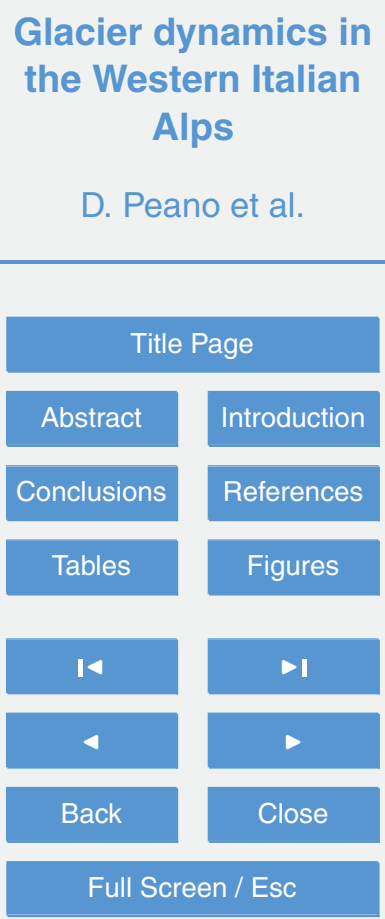

Printer-friendly Version

Interactive Discussion 


\subsubsection{Basei, Bessanese, and Capra glaciers}

These three glaciers show a good agreement between measured and modeled values (Fig. $6 a-C)$. The main feature for Basei, Bessanese, and Capra is the presence of a gap in the observation during the two decades from 1970 to 1990. In those years, a short 5 re-advance period is documented for the Alpine glaciers (Zemp et al., 2008, 2006), and the model reproduces this increase in glacier length. This reconstruction supports the presented method since it adds information on the glacier evolution during the period in which these glaciers were not surveyed.

\subsubsection{Lys, and Prè de Bar glaciers}

10 These two glaciers present a measured line much smoother than the modeled one (Fig. 6d and h). This discrepancy can be attributed to the difference between the instantaneous response time assumed by the model and the actual finite response of glacier length, which is delayed, filtered (high frequency cutting) and conditioned by glacier dynamics (Thibert et al., 2013). The approximation of instantaneous response 15 works quite well for small glaciers, for which the time required for the mass transfer from the accumulation area to the front is short, while larger glaciers, such as Lys and Prè de Bar glaciers, have a larger response time that redistributes over several years the effects of climatic variations, leading to a "smoothing effect" on its measured length variation series (Calmanti et al., 2007; Bonanno et al., 2013).

20 Different works (e.g. Johannesson et al., 1989; Van de Wal and Oerlemans, 1995) show how the response time is influenced by the glacier volume and dynamics. Another relevant factor which may contribute to the peculiar behavior of these two glaciers is glacier hypsometry (Raper and Braithwaite, 2009): Lys and Prè de Bar glaciers, in addition to being the largest ones of the considered sample, are also located to the winter precipitation is the relevant value for mass balance, might be incorrect. Furthermore, ablation and accumulation seasons in this work are considered fixed, but these

Glacier dynamics in the Western Italian Alps

D. Peano et al.

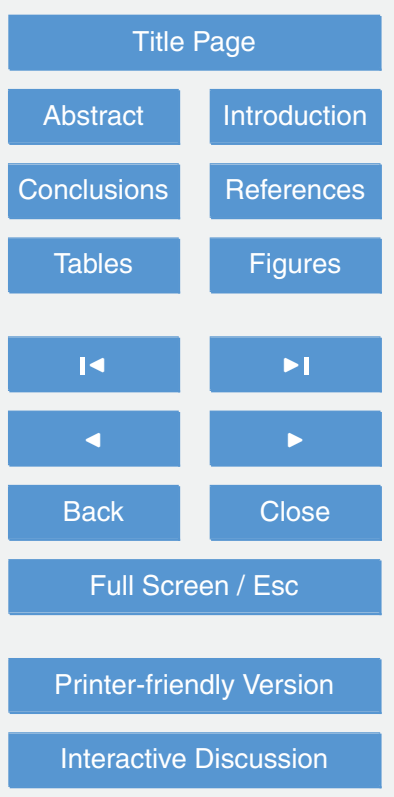


seasons timing is different for each glacier, especially for the larger ones, and are also changing in time, for example the ablation season has become longer in Alpine region during the last decades (Thibert et al., 2013). Finally these two glaciers, also because of their extension, have a more complex setting: they are both characterized by a well 5 defined tongue, which connect to the accumulation area through a marked rock step. The tongue of the Lys Glacier, in addition, is feeded by two separate accumulation basins.

In this case, the absence of measured mass balance series creates a lack of knowledge which cannot be compensated with the empirical method presented.

\subsubsection{Moncorvè, Mulinet Nord, Mulinet Sud, and Valtournanche glaciers}

In the case of these glaciers, the model reproduces well the measured length oscillations (Fig. $6 e-g$ and i). It has to be pointed out that Moncorvè, Mulinet Nord, Mulinet Sud, and Valtournanche glaciers show a predominance of the third term $(c)$, see Table 3, which represents the influence of external forcing different from October-May precipitation and June-September temperature changes, such as glacier shape, topography or direct radiation. This strong dependence on the last parameter explain the almost linear shape of the modeled length variations of these four glaciers.

The reproduction of the length dynamics of these glaciers highlights another limit of the minimal models used here: the considered forcings are the climatic ones (June20 September temperature and October-May precipitation), while other features such as shape, mean aspect, slope, debris coverage, etc. are described by the $c$ term of Eq. (5). Only more complex model can give a better understanding of the influence of each of these non-climatic features.

\section{TCD}

$8,1479-1516,2014$

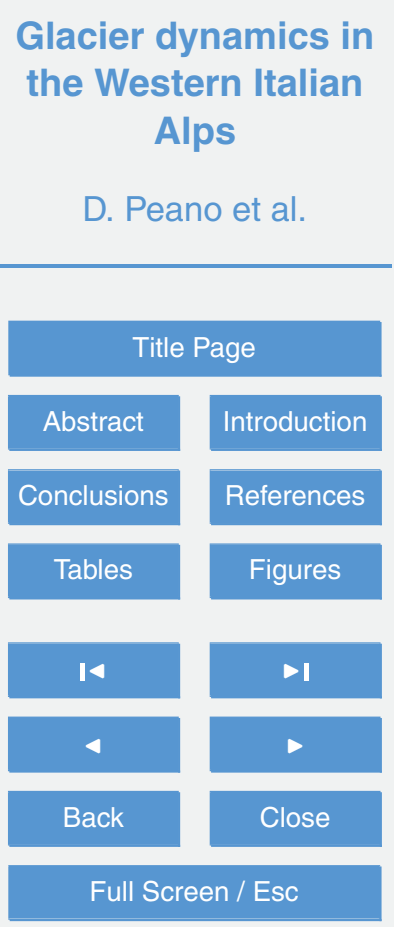

Printer-friendly Version

Interactive Discussion 


\section{Future projections}

One of the main aims of using glacier models is to estimate future glacier evolution. This can be done with the aid of future climate scenario projections from global climate models. In this work we use an ensemble of RCP 4.5 and RCP 8.5 scenarios pro5 duced with the global model EC-Earth for the Climate Model Intercomparison Project 5 (CMIP5).

Figure 7 shows the future evolution of temperature and precipitation, for the seven monthly ensemble members for RCP 4.5 and the eight monthly ensemble members for RCP 8.5, in the pixel of the EC-Earth model grid containing most of the glaciers.

10 Figure $7 a$ shows no great difference in precipitation in the two considered scenarios, but Fig. 7b shows a considerable difference in the temperature evolution, with the temperatures increasing significantly more in the RCP 8.5 scenario compared to the RCP 4.5 scenario.

Using these climate projections, we estimate the future evolution of each glacier 15 analyzed in Sect. 4 using the dynamical model for length (Eq. 4) and the same parameters for Eq. (5) found in the historical period, but keeping in mind the limitations of our method, such as using a "box" shape for the glacier, considering an immediate response of the glacier to climate forcing, and assuming a constant value in time for the model parameters $\left(a, b, c, \alpha_{\mathrm{m}}\right.$ and $\left.v\right)$. For each glacier we force the model with temperature and precipitation series ranging from 1959 to 2100 for the corresponding pixel of the EC-Earth model grid.

The annual series of mean temperature and total precipitation are standardized using 1971-2000 as a reference period. Subsequently, the mass balance series are obtained using Eq. (5), with the parameters values reported in Tables 2 and 3. Finally the minimal model Eq. (4) can be applied, using the geometry information in Table 1. Figure 8 shows the future evolution of the eleven studied glaciers using the RCP 4.5 and RCP 8.5 scenarios ensemble. The gray bands indicate the range in lengths covered by the ensemble members.

Glacier dynamics in the Western Italian Alps

D. Peano et al.

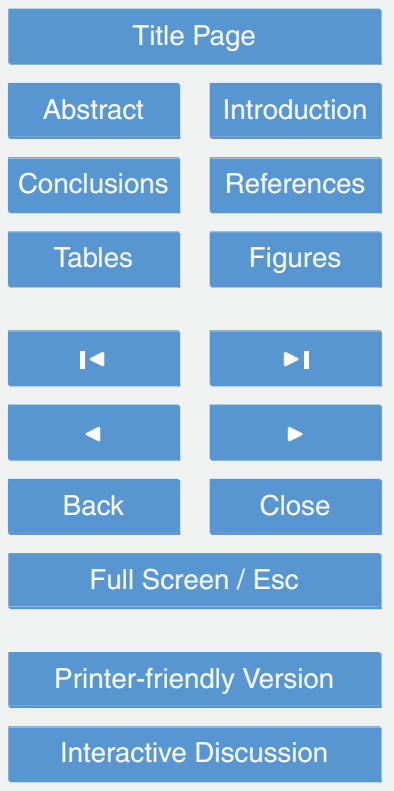


The eleven glaciers present, as a common behavior, a decrease in glacier length, with a severe shrinkage by the end of this century, which is in line with the simulated variations by previous works (e.g. Zemp et al., 2006; Salzmann et al., 2012; Linsbauer et al., 2013). The RCP 8.5 scenario presents a larger glacier retreat with respect to 5 RCP 4.5 scenario. This difference can be attributed to its higher predicted increase in temperature (Fig. 7b). Each glacier shows a different behavior according to the different influence of the two climatic variables on the mass balance relation (see Tables 2 and $3)$. In general, glaciers with a stronger influence of the third term, $c$, present a smaller ensemble spread, while glaciers with large values of $a$ and $b$ show a larger ensemble spread and a larger difference between the two scenarios.

The Prè de Bar Glacier is the only glacier predicted to disappear before the year 2100. In the RCP 4.5 scenario forecasts the glacier disappearance in the period 20802100 , while RCP 8.5 scenario in the period 2070-2080. It is important to recall that the Prè de Bar Glacier behavior, due to its dimensions and others features, is not very well described by the simple model used in this work, so that this prediction should be considered with caution. Anyhow, more complex models show also a retreating behavior for Alpine glaciers during the 21st century, and even large glaciers have been predicted to have a strong shrinkage during this century (e.g. Jouvet et al., 2011; LeMeur et al., 2007).

20 The model results indicate that the eleven glaciers considered here are going to decrease in length during this century and that the rate of retreat depends strongly on the future scenario which is used. Some mechanisms, which are not considered in this work, such as change in debris cover or glacier breaking apart, could change the glacier retreating behavior. Nevertheless, the model results presented here can give, at least, an order of magnitude estimation of glaciers retreat during this century, and the absence of information on ice thickness force us to consider these length variations representative also for the future evolution of the volume of the glaciers.

TCD

$8,1479-1516,2014$

Glacier dynamics in the Western Italian Alps

D. Peano et al.

Title Page

Abstract Introduction

Conclusions References

Tables Figures

14 DI

4

Back

Close

Full Screen / Esc

Printer-friendly Version

Interactive Discussion 


\section{Conclusions}

The application of the minimal model illustrated in this paper to a sample of glaciers in the Western Italian Alps confirms that modeling glacier dynamics is a complex task. In fact, the considered glaciers show very different behaviors in response to climate forc5 ing, even if they share a similar climatic, geographic and geologic setting. This outcome can be partly explained with the different volume of the studied glaciers, whose surface ranges from 0.2 to over $9 \mathrm{~km}^{2}$. For the largest glaciers (Lys and Prè de Bar), the delay of glacier response to climatic parameters has to be taken into account. This effect is particularly relevant when mass balance data are not available and glacier dynamics has to be inferred only from changes of glacier length.

The smaller glaciers show different behaviors with respect to climatic parameters: some of them (Capra, Basei) appear to be mainly influenced by JuneSeptember temperature, while others resulted more sensitive to October-May precipitation (Bessanese, Grand Etrèt). This unexpected behavior, can be linked to the shortage of available measurements and to a larger influence of local features, especially for the Grand Etrèt case, but we observe that this type of behavior is not unique in the Alps (Vincent et al., 2005).

Finally, for a third group of glaciers, additional factors other than climatic parameters appear to play an important role (Moncorvé, Mulinet Nord, Mulinet Sud, and Valtournanche). While more complex models may be better suited to model the response of such glaciers, the absence of some information, starting from the ice thickness profile along the flow line, limit the complexity of the applicable models. For example, the high order flow line model presented by Pattyn (2002) cannot be used here. In these cases the varying ice thickness profile could be only estimated using a general/theoretical profile, e.g. using the A-V method presented by Harrison (2013) or the method by Huss and Farinotti (2012).

When we consider future projections, the first group of glaciers which is influenced mainly by temperature in the historical period, shows also a higher retreat in length,

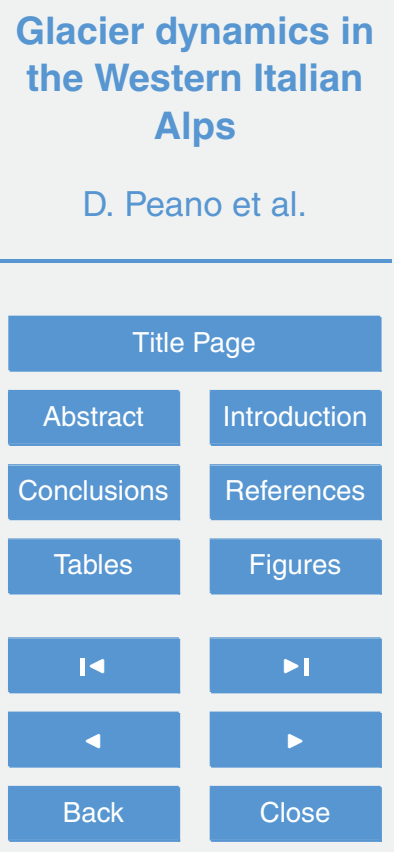

Full Screen / Esc

Printer-friendly Version

Interactive Discussion 
i.e. both Capra and Basei reach zero length around 2100 in the RCP 8.5 scenario (Fig. 8c and e). The other glaciers show a slower retreat, see for example the Grand Etrèt (Fig. 8b).

Among the eleven glaciers which we considered, the Ciardoney Glacier presents the 5 longest series of measured mass balances, and also a complete series of measured frontal length variations: this wealth of data makes the Ciardoney Glacier the most reliable study case for testing past reconstruction and future prediction of glacier change in response to climate variability.

Glacier volume, form, altitude, slope, and aspect can significantly contribute to deter10 mine glacier dynamics in response to climate forcing. However, it is difficult to establish the specific weight of each of these factors as no univocal contribution come on the topic from the published literature: in order to take them into account, it would be necessary to use models that are much more complex than those used in this work. In particular the applicability of the model to evaluate future projections is constrained by these factors. We assume a constant value in time for the model parameters but we don't have any information on how the climate features will influence the glacier surface mass balance in future, and, as shown in Sect. 4.1, our approach is sensitive to changes in the $a, b, c$ parameters values. This assumption, then, limits the length of our future simulations. Further, we do not have information on ice thickness and we cannot provide accurate estimates of future volume changes. A better estimate of volume changes could be obtained by linking the length variations to the volume oscillations using a simple relation, such as the LV method described in the work by Lüthi et al. (2010).

The minimal model presented here, however, has been shown to be a useful tool 25 for a rapid, preliminary assessment of the sensitivity of small glaciers (which are the majority of glaciers in the Italian Alps) to regionalized climatic parameters and is suitable to simulate the evolution of these glaciers in response to different future climate scenarios.

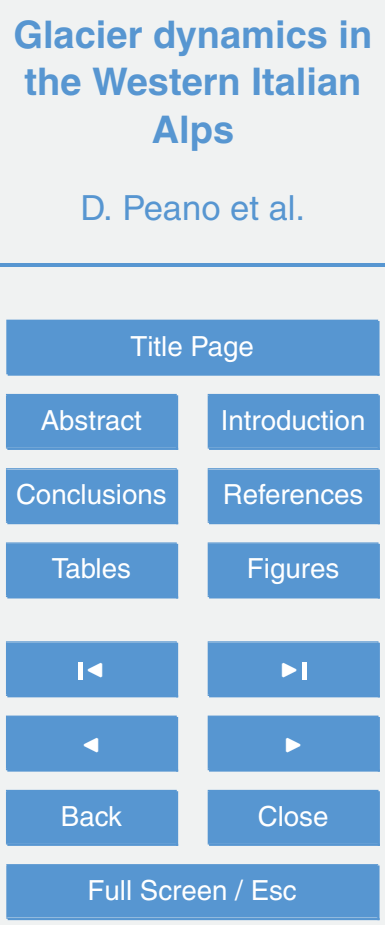

Printer-friendly Version

Interactive Discussion 


\section{Appendix A}

\section{Physical properties of the glaciers considered in this study}

\section{A1 Ciardoney}

The Ciardoney glacier lies on the southern flank of the Gran Paradiso massif, in a cir5 cus located at the head of the Forzo valley. It has a surface of only $0.58 \mathrm{~km}^{2}$, but it ranks third among the glaciers of the Orco and Soana valleys. Its morphological characteristics (low surface gradient and limited crevassing) make the Ciardoney Glacier very suitable for glaciological measures. Starting in 1992, it has thus become the object of a series of mass balance measurements which now has few equals in the Italian

10 Alps, for its length and completeness (Mercalli and Berro, 2005). In addition, the glacier, whose elevation presently ranges from 3140 to 2850 ma.s.l., has a quite regular shape, with a present length of $1350 \mathrm{~m}$ and a maximum width of $580 \mathrm{~m}$, and a uniform aspect, and is thus also suitable for our modeling purposes (Fig. 4).

The Ciardoney Glacier has a quite long record of measured length variations, 28 15 measures for the period 1971-2009, and 18 measures of mass balance and ELA position from 1992 to 2009 (Fig. 2a, Mercalli and Berro, 2005).

\section{A2 Grand Etrèt}

The glacier occupies the head of the Valsavaranche Valley, on the northern flank of the Gran Paradiso massif, and has a prevalent N aspect. Since 1999, it has been chosen for mass balance measures, as representative of glaciers behavior on the northern side of the Gran Paradiso National Park (Bertoglio and Cerise, 2008). In fact, it has a fairly small area $\left(0.56 \mathrm{~km}^{2}\right)$, together with a low gradient and smooth surface. Due to the enhanced shrinkage occurred in the last decades, the current shape of the glacier is quite regular and therefore suitable for the geometry simplification required by the

model. According to the glacier inventory ("Catasto Ghiacciai") of the Valle d'Aosta

Glacier dynamics in the Western Italian Alps

D. Peano et al.

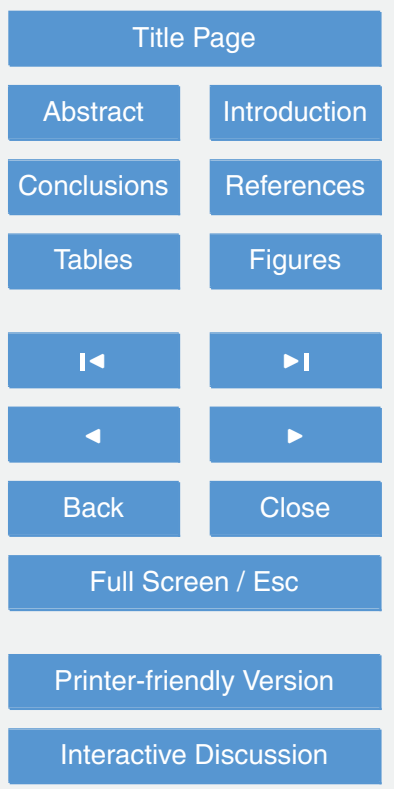

Interactive Discussion 
Region, the glacier ranges in elevation from 3100 to 2700 ma.s.l.; in 1999, its maximum length was $1.35 \mathrm{~km}$, and its maximum width was $0.87 \mathrm{~km}$. A Ground Penetrating Radar (GPR) survey performed in 2006 showed that the glacier reaches a thickness of $43 \mathrm{~m}$ in its central portion.

5 The Grand Etrèt Glacier has a series of 10 measured mass balances and ELA positions (provided by GPNP), and a slightly longer series of measured length variations (provided by CGI). This glacier has been chosen with the aim of comparing with the model outcomes for the Ciardoney model, considered that these two glaciers are very close in space and are therefore exposed to similar climatic variations. The available data are reported in Fig. 2b.

\section{A3 Basei}

The glacier covers the northeastern flank of the Basei Peak (Gran Paradiso massif), from an elevation of $3300 \mathrm{~m}$ to 2950 ma.s.l. The current (2006) area is about $0.26 \mathrm{~km}^{2}$, while the maximum length and width are respectively 0.85 and $0.50 \mathrm{~km}$. Thanks to the lack of high rock walls around the glacier, its surface is free of debris, at variance to most other glaciers that are also experiencing a prolonged phase of retreat. Due to its location in a glacial depression, changes in length in response to climatic factors are less marked than for other glaciers (e.g. Ciardoney Glacier).

\section{A4 Bessanese}

20 In the Valle Grande di Lanzo, the Bessanese Peak dominates the large cirque hosting the glacier, whose maximum altitude is 3220 ma.s.l. The glacier has a well developed tongue (a smaller one, on the left side of the glacier, is now extinct), which flows down to an elevation of 2580 ma.s.l. and is now masked by a thick debris cover, as a result of the marked retreat of the last decades. The overall area, facing S-SE, was $0.50 \mathrm{~km}^{2}$ in 2006, with a maximum length of almost $2 \mathrm{~km}$ and a maximum width of about $0.7 \mathrm{~km}$.

Glacier dynamics in the Western Italian Alps

D. Peano et al.

Title Page

Abstract

Introduction

Conclusions

References

Tables

Figures

14

DI

4

Back

Close

Full Screen / Esc

Printer-friendly Version

Interactive Discussion 


\section{A5 Capra}

Thanks also to its NNE exposition, this glacier has the lowest front elevation ( 2450 ma.s.l.) of the entire Gran Paradiso massif, while its maximum altitude is 2800 ma.s.l. The glacier $\left(0.25 \mathrm{~km}^{2}\right)$ is composed of an accumulation area located in

5 a well-defined cirque, and of the remains of a tongue, which during the Little lce Age has built impressive lateral moraines and is now completely covered with debris. Total glacier length is about $0.9 \mathrm{~km}$, and its maximum width is $0.5 \mathrm{~km}$.

\section{A6 Lys}

It is the largest glacier considered in this study $\left(9.59 \mathrm{~km}^{2}\right.$ in 2005). It is located on the 10 southern flank of the Monte Rosa massif and is closed to the North by the Eastern Liskamm crest. It is formed by a compound accumulation area reaching a maximum elevation of 4350 ma.s.l., feeding two distinct branches which join at an elevation of about $2700 \mathrm{~m}$ to form a single, large tongue (named "Plateau"), flowing down to an altitude of $2355 \mathrm{~m}$. Maximum length and width, measured in 1999, were respectively

\section{A7 Moncorvè}

The main glacial body is currently resting along the northern side of the Ciarforón Peak (Gran Paradiso), with a smaller body on the western flank of the Tresenta Peak, which is on the point of detaching from the main one to the east. The glacier has an area of about $1.3 \mathrm{~km}^{2}$ and is more developed in width than in length $(1.5 \mathrm{~km}$ and $2.0 \mathrm{~km}$ respectively, measured in 1999). Glacier elevation ranges from $3640 \mathrm{~m}$ to about $2900 \mathrm{~m}$, with the front plunging in a large moraine lake.

Glacier dynamics in the Western Italian Alps

D. Peano et al.

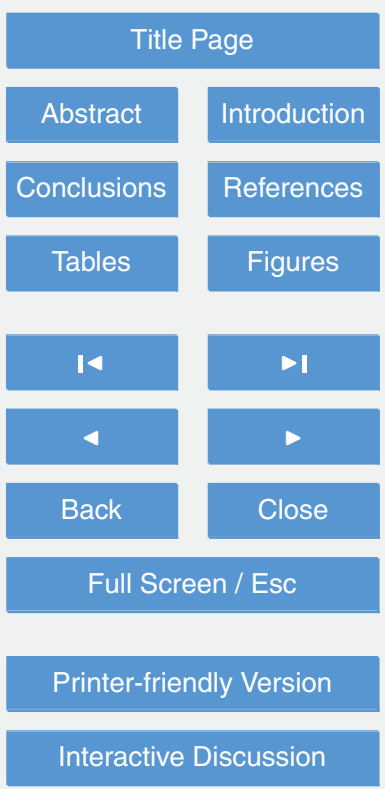




\section{A8 Mulinet Nord and Mulinet Sud}

These two glaciers occupy two adjoining topographic depressions in a large cirque between the Monfret and Martellot peaks (Valle Grande di Lanzo). They used to be a unique glacier at the beginning of the 20th century, but the subsequent phase of 5 glacier retreat led to the separation of the Mulinet Glacier in two bodies of similar surface $\left(0.2 \mathrm{~km}^{2}\right.$ and $0.3 \mathrm{~km}^{2}$, respectively, in 2006). After the marked retreat of the last decades, the glaciers have now a quite regular, almost rounded shape. The maximum elevation reached by the glaciers is about $3000 \mathrm{~m}$, while the front is now located at about $2700 \mathrm{~m}$, after that in 2007 the small tongues detached from the accumulation areas, in correspondence of the rock step which borders the glacial cirque towards valley.

\section{A9 Prè de Bar}

Located at the very end of the Ferret Valley (Mont Blanc), this glacier has a surface of about $3 \mathrm{~km}^{2}$. It is one of the most famous glaciers of the Aosta Valley, because of

its distinctive lobated tongue, easily accessible from the main valley bottom. In the last few years, though, the morphology of the glacier front has changed dramatically, with a marked regression of the glacial tongue (at an approximate elevation of 2090 ma.s.I.), which during the summer 2012 finally detached from the accumulation basin, in correspondence of a marked rock step. Glacier maximum length and width were respectively

Glacier dynamics in the Western Italian Alps

D. Peano et al.

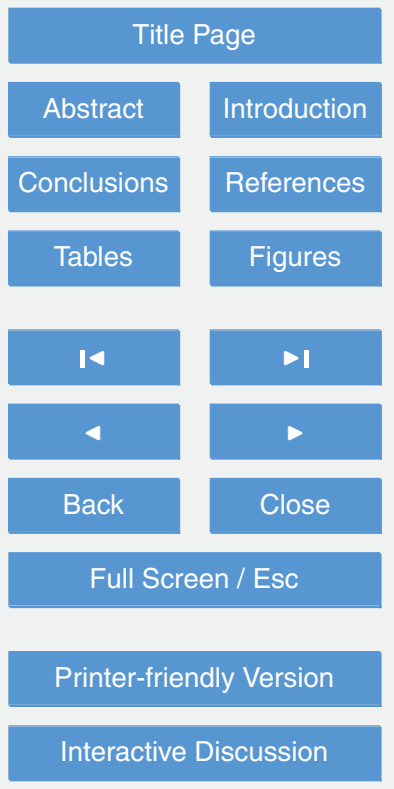
Peak (3480 ma.s.I.) and the Gobba di Rollin, in Valtournanche (Monte Rosa group). The glacier front is now at an elevation of about $3000 \mathrm{~m}$.

\section{A10 Valtournanche}


Acknowledgements. We thank L. Mercalli and D. Cat Berro of SMl for the Ciardoney data, S. Cerise and V. Bertoglio of GPNP for the Grant Etret data and S. Bertotto for providing the initial geometric data of the glaciers. We are grateful to the voluntary personnel of the Italian Glaciological Committee for monitoring glacier snout fluctuations. Without the dedicated efforts 5 of all these field observers and scientists, studies like this one could not be perfomed. This work has been supported by the Project of Interest NextData of the Italian Ministry of University, Education and Research (MIUR).

\section{References}

Ajassa, R., Biancotti, A., Biasini, A., Brancucci, G., Carton, A., and Salvatore, M. C.: Changes in the number and area of Italian Alpine glaciers between 1958 and 1989, Geogr. Fis. Din. Quat., 20, 293-297, 1997. 1482

Beniston, M.: Impacts of climatic change on water and associated economic activities in the Swiss Alps, J. Hydrol., 412-413, 291-296, 2012. 1480

Bertoglio, V. and Cerise, S.: Evoluzione del ghiacciaio del Grand Etret, in: Environnement, 41, Regione Autonoma Valle d'Aosta, available at: https://www.regione.vda.it/gestione/riviweb/ templates/aspx/environnement.aspx?pkArt=383 (last access: July 2012), 2008. 1498

Bonanno, R., Ronchi, C., Cagnazzi, B., and Provenzale, A.: Glacier response to current climate change and future scenarios in the northwestern Italian Alps, Reg. Environ. Change, 13, 1-11, 2013. 1480, 1481, 1483, 1492

Braun, L. N., Weber, M., and Schulz, M.: Consequences of climate change for runoff from Alpine regions, Ann. Glaciol., 31, 19-25, 2000. 1480

Brunetti, M., Maugeri, M., Monti, F., and Nanni, T.: Temperature and precipitation variability in Italy in the last two centuries from homogenised instrumental time series, Int. J. Climatol., 26, 345-381, 2006. 1480

25 Calmanti, S., Motta, L., Turco, M., and Provenzale, A.: Impact of climate variability on Alpine glaciers in northwestern Italy, Int. J. Climatol., 27, 2041-2053, 2007. 1481, 1486, 1487, 1492

Chiarle, M. and Mortara, G.: Geomorphological impact of climate change on alpine glacial and periglacial areas. Examples of processes and description of research needs, in: Interpraevent 2008 - Conference Proceedings, Dornbirn, 26-30 May 2008, 111-122, 2008. 1480 
Deline, P., Gardent, M., Magnin, F., and Ravanel, L.: The morphodynamics of the Mont Blanc massif in a changing cryosphere: a comprehensive review, Geogr. Ann. A, 94, 265-283, 2012. 1480

Diolaiuti, G. A., Bocchiola, D., Vagliasindi, M., D’Agata, C., and Smiraglia, C.: The 1975-2005 glacier changes in Aosta Valley (Italy) and the relations with climate evolution, Prog. Phys. Geog., 36, 764-785, 2012. 1491

Harrison, W. D.: How do glaciers respond to climate? Perspectives from the simplest models, J. Glaciol., 59, 949-960, 2013. 1496

Hazeleger, W., Wang, X., Severijns, C., Ştefănescu, S., Bintanja, R., Sterl, A., Wyser, K., Semmler, T., Yang, S., van den Hurk, B., van Noije, T., van der Linden, E., and van der Wiel, K.: EC-Earth V2.2: description and validation of a new seamless earth system prediction model, Clim. Dynam., 39, 2611-2629, 2012. 1483

Huss, M. and Farinotti, D.: Distributed ice thickness and volume of all glaciers around the globe, J. Geophys. Res., 117, F04010, doi:10.1029/2012JF002523, 2012. 1496

15 Johannesson, T., Raymond, C., and Waddington, E.: Time-scale for adjustment of glaciers to changes in mass balance, J. Glaciol., 35, 355-369, 1989. 1492

Jouvet, G., Huss, M., Funk, M., and Blatter, H.: Modelling the retreat of Grosser Aletschgletscher, Switzerland, in a changing climate, J. Glaciol., 57, 1033-1045, 2011. 1495

Kääb, A., Chiarle, M., Raup, B., and Schneider, C.: Climate change impacts on mountain glaciers and permafrost, Global Planet. Change, 56, 7-9, 2007. 1480

Kuhn, M.: Fluctations of climate and mass balance: different responses of two adjacent glaciers, Z. Gletscherk. Glazialgeol., 21, 409-416, 1985. 1489

LeMeur, E., Gerbaux, M., Schäfer, M., and Vincent, C.: Disappearance of an Alpine glacier over the 21 st century simulated from modeling its future surface mass balance, Earth Planet. Sc. Lett., 261, 367-374, 2007. 1495

Linsbauer, A., Paul, F., Machguth, H., and Haeberli, W.: Comparing three different methods to model scenarios of future glacier change in the Swiss Alps, Ann. Glaciol., 54, 241-253, 2013. 1495

Lüthi, M. P., Bauder, A., and Funk, M.: Volume change reconstruction of Swiss glaciers from 30 length change data, J. Geophys. Res., 115, F04022, doi:10.1029/2010JF001695, 2010. 1497

Mercalli, L. and Berro, D. C.: Clima acque e ghiacciai tra Gran Paradiso e Canavese, 1st edn., Societá Meteorologica Subalpina, Bussoleno (TO), Italy, 2005. 1486, 1498
TCD

$8,1479-1516,2014$

Glacier dynamics in the Western Italian Alps

D. Peano et al.

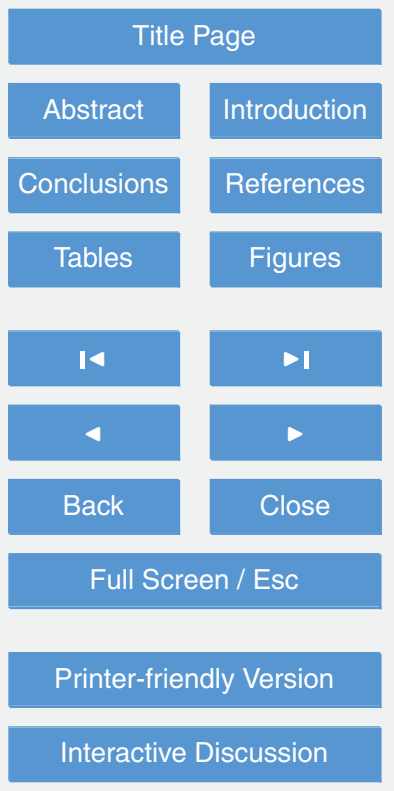


Nesje, A. and Dahl, S. O.: Glaciers and Environmental Change, 1st edn., Arnold, London, England, 2000. 1480

Oerlemans, J.: A flowline model for Nigardsbreen, Norway: projection of future glacier length based on dynamic calibration with the historic record, J. Glaciol., 24, 382-389, 1997. 1481

5 Oerlemans, J.: Glaciers and Climate Change, 1st edn., A. A. Balkema Publisher, Rotterdam, the Netherlands, 2001. 1484

Oerlemans, J.: The Microclimate of Valley Glaciers, Igitur, 1st print edn., Utrecht Publishing \& Archiving Services, Universiteitsbibliotheek Utrecht, the Netherlands, 2010. 1485

Oerlemans, J.: Minimal Glacier Models, Igitur, 2nd print edn., Utrecht Publishing \& Archiving Services, Universiteitsbibliotheek Utrecht, the Netherlands, 2011. 1481, 1484, 1485

Oerlemans, J., Jania, J., and Kolondra, L.: Application of a minimal glacier model to Hansbreen, Svalbard, The Cryosphere, 5, 1-11, doi:10.5194/tc-5-1-2011, 2011. 1481, 1484

Pattyn, F.: Transient glacier response with a higher-order numerical ice-flow model, J. Glaciol., 48, 467-477, 2002. 1481, 1496

Paul, F., Kääb, A., Maisch, M., Kellenberger, T., and Haeberli, W.: Rapid disintegration of Alpine glaciers observed with satellite data, Geophys. Res. Lett., 31, L21402, doi:10.1029/2004GL020816, 2004. 1491

Raper, S. C. B. and Braithwaite, R. J.: Glacier volume response time and its links to climate and topography based on a conceptual model of glacier hypsometry, The Cryosphere, 3, 183-194, doi:10.5194/tc-3-183-2009, 2009. 1492

Salzmann, N., Machguth, H., and Linsbauer, A.: The Swiss Alpine glaciers' response to the global " $2{ }^{\circ} \mathrm{C}$ air temperature target", Environ. Res. Lett., 7, 044001, doi:10.1088/17489326/7/4/044001, 2012. 1495

Steiner, D., Pauling, A., Nussbaumer, S. U., Nesje, A., Luterbacher, J., Wanner, H., and Zumbühl, H. J.: Sensitivity of European glaciers to precipitation and temperature - two case studies, Climatic Change, 90, 413-441, 2008. 1489

Stoffel, M. and Huggel, C.: Effects of climate change on mass movements in mountain environments, Prog. Phys. Geog., 36, 421-439, 2012. 1480

Thibert, E., Eckert, N., and Vincent, C.: Climatic drivers of seasonal glacier mass balances: 30 an analysis of 6 decades at Glacier de Sarennes (French Alps), The Cryosphere, 7, 47-66, doi:10.5194/tc-7-47-2013, 2013. 1489, 1492, 1493

Glacier dynamics in the Western Italian Alps

D. Peano et al.

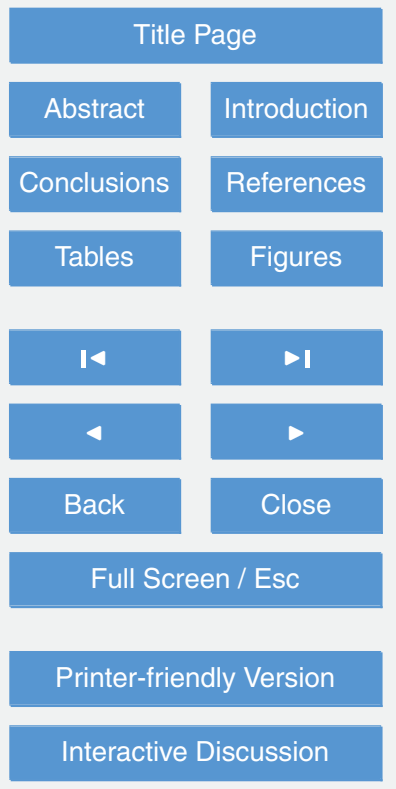


Uboldi, F., Lussana, C., and Salvati, M.: Three-dimensional spatial interpolation of surface meteorological observations from high-resolution local networks, Meteorol. Appl., 15, 331-345, 2008. 1483

Van de Wal, R. S. W. and Oerlemans, J.: Response of valley glaciers to climate change and $5 \quad$ kinematic waves: a study with a numerical ice-flow model, J. Glaciol., 41, 142-152, 1995. 1492

Vincent, C., LeMeur, E., Six, D., and Funk, M.: Solving the paradox of the end of the Little Ice Age in the Alps, Geophys. Res. Lett., 32, L09706, doi:10.1029/2005GL022552, 2005. 1489, 1496

10 Viviroli, D., Archer, D. R., Buytaert, W., Fowler, H. J., Greenwood, G. B., Hamlet, A. F., Huang, Y., Koboltschnig, G., Litaor, M. I., López-Moreno, J. I., Lorentz, S., Schädler, B., Schreier, H., Schwaiger, K., Vuille, M., and Woods, R.: Climate change and mountain water resources: overview and recommendations for research, management and policy, Hydrol. Earth Syst. Sci., 15, 471-504, doi:10.5194/hess-15-471-2011, 2011. 1480

Winkler, S., Chinn, T., Gärtner-Roer, I., Nussbaumer, S. U., Zemp, M., and Zumbühl, H. J.: An introduction to mountain glaciers as climate indicators with spatial and temporal diversity, ERDKUNDE, 64, 97-118, doi:10.3112/erdkunde.2010.02.01, 2010. 1489

Zemp, M., Haeberli, W., Hoelzle, M., and Paul, F.: Alpine glaciers to disappear within decades?, Geophys. Res. Lett., 33, L13504, doi:10.1029/2006GL026319, 2006. 1492, 1495

Zemp, M., Paul, F., Hoelzle, M., and Haeberli, W.: Glacier fluctuations in the European Alps 1850-2000: an overview and spatio-temporal analysis of available data, in: The Darkening Peaks: Glacial Retreat in Scientific and Social Context, edited by: Orlove, B., Wiegandt, E., and Luckman, B., University of California Press, Berkeley, 152-167, 2008. 1480, 1492

Zwinger, T., Greve, R., Gagliardini, O., Shiraiwa, T., and Lyly, M.: A full Stokes-flow thermomechanical model for firn and ice applied to the Gorshkov crater glacier, Kamchatka, Ann. Glaciol., 45, 29-37, 2007. 1481

Glacier dynamics in the Western Italian Alps

D. Peano et al.

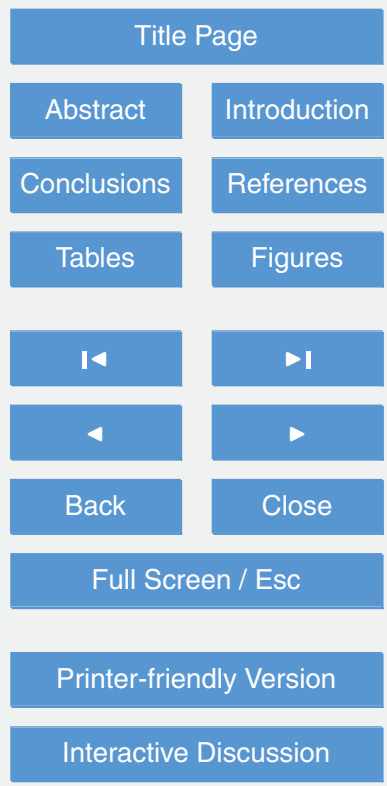


Table 1. Values of the geometrical parameters used to describe the geometry of the studied glaciers. The initial year of the series of measured values and the number of measured years are reported in the second and third columns respectively. $L_{\mathrm{yrl}}$ represents the glacier length at the initial year, these values have been obtained by adding the length oscillations measured on field to the glacier length acquired in a GIS environment using the 2000 or 2006 aerial photos; $b_{0}$ is the elevation of the glacier's head; $s$ is the estimated mean slope of the glacier's bed; $\alpha_{\mathrm{m}}$ and $v$ are the best values for the two parameters used to describe the relation between glacier length and mean glacier thickness (see Eq. 1). The values of $L_{\mathrm{yrl}}, b_{0}$ and $s$ have been measured using GIS tools.

\begin{tabular}{lcccccrll}
\hline Glacier & $\begin{array}{c}\text { first } \\
\text { year }\end{array}$ & \#years & $\begin{array}{c}L_{\mathrm{yrl}} \\
{[\mathrm{m}]}\end{array}$ & $\begin{array}{c}b_{0} \\
{[\mathrm{~m} \text { a.s.I. }]}\end{array}$ & $s$ & $\begin{array}{r}\alpha_{\mathrm{m}} \\
{\left[m^{\frac{1}{2}}\right]}\end{array}$ & $v$ & mean asp. \\
\hline Ciardoney & 1971 & 28 & 1660 & 3150 & 0.14 & 7.0 & 10.0 & $\mathrm{E}$ \\
Grand Etrèt & 1997 & 12 & 1310 & 3100 & 0.29 & 11.0 & 10.0 & $\mathrm{NW}$ \\
Basei & 1968 & 27 & 727 & 3300 & 0.48 & 7.0 & 10.0 & $\mathrm{~N}-\mathrm{NE}$ \\
Bessanese & 1973 & 22 & 1866 & 3220 & 0.34 & 7.0 & 10.0 & $\mathrm{E}-\mathrm{SE}$ \\
Capra & 1959 & 20 & 942 & 2790 & 0.33 & 7.0 & 10.0 & $\mathrm{~N}-\mathrm{NE}$ \\
Lys & 1977 & 33 & 5169 & 4350 & 0.34 & 7.0 & 10.0 & $\mathrm{SW}$ \\
Moncorvè & 1986 & 20 & 1603 & 3640 & 0.50 & 7.0 & 10.0 & $\mathrm{~W}$ \\
Mulinet Nord & 1989 & 17 & 432 & 2980 & 0.50 & 7.0 & 10.0 & $\mathrm{E}-\mathrm{SE}$ \\
Mulinet Sud & 1989 & 16 & 762 & 3000 & 0.39 & 7.0 & 10.0 & $\mathrm{E}$ \\
Prè de Bar & 1959 & 49 & 3342 & 3700 & 0.43 & 7.0 & 10.0 & $\mathrm{SE}$ \\
Valtournanche & 1969 & 27 & 1600 & 3590 & 0.38 & 7.0 & 10.0 & $\mathrm{~W}$ \\
\hline
\end{tabular}

8, 1479-1516, 2014

Glacier dynamics in the Western Italian Alps

D. Peano et al.

\section{Title Page}

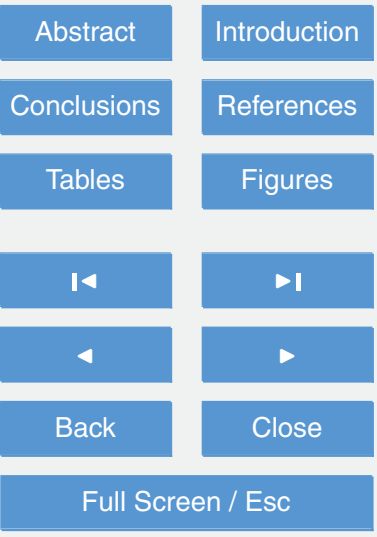

Printer-friendly Version

Interactive Discussion 
Table 2. Values of the parameters used in the relation between mass balance and climatic variables for Ciardoney glacier and Grand Etrèt glacier. (Measured) refers to values obtained directly using the measured mass balance, standard June-September temperature and standard October-May precipitation series. (Model) refers to values obtained with the minimization of the root mean squared difference, $D$, between the measured glacier length variations and the modeled ones (reported in the rightmost column).

\begin{tabular}{lcccc}
\hline Glacier & $\begin{array}{c}a \\
{\left[\text { mweyear }^{-1}\right]}\end{array}$ & $\begin{array}{c}b \\
{\left[\text { mweyear }^{-1}\right]}\end{array}$ & $\begin{array}{c}c \\
{\left[\text { mweyear }^{-1}\right]}\end{array}$ & $\begin{array}{r}D(a, b, c) \\
{[\mathrm{m}]}\end{array}$ \\
\hline Ciardoney (measured) & -0.48 & 0.63 & -0.85 & \\
Ciardoney (model) & -0.44 & 0.75 & -0.78 & 11.1 \\
Grand Etrèt (measured) & 0.06 & 0.67 & -0.97 & \\
Grand Etrèt (model) & -0.01 & 0.37 & -0.98 & 4.1 \\
\hline
\end{tabular}

Glacier dynamics in the Western Italian Alps

D. Peano et al.

Title Page

Abstract

Conclusions

Tables

14

4

Back
Introduction

References

Figures

DI

$>$

Close

Full Screen / Esc

Printer-friendly Version

Interactive Discussion 
Table 3. Values of the three parameters for Eq. (5) used in the mass balance reconstruction, obtained with the minimization of the root mean squared difference, $D$, between the measured glacier length variations and the modeled ones (reported in the rightmost column).

\begin{tabular}{lcccr}
\hline Glacier & $\begin{array}{c}a \\
{\left[\text { mweyear }^{-1}\right]}\end{array}$ & $\begin{array}{c}b \\
{\left[\text { mweyear }^{-1}\right]}\end{array}$ & $\begin{array}{c}c \\
{\left[\text { mweyear }^{-1}\right]}\end{array}$ & $\begin{array}{c}D(a, b, c) \\
{[\mathrm{m}]}\end{array}$ \\
\hline Basei & -0.22 & 0.01 & -0.06 & 3.5 \\
Bessanese & -0.11 & 0.13 & 0.01 & 1.7 \\
Capra & -0.28 & 0.18 & -0.18 & 3.8 \\
Lys & -0.39 & 0.90 & 0.01 & 31.0 \\
Moncorvè & -0.14 & -0.02 & -0.15 & 5.7 \\
Mulinet Nord & -0.03 & -0.04 & -0.10 & 1.6 \\
Mulinet Sud & -0.06 & -0.04 & -0.25 & 2.8 \\
Prè de Bar & -0.82 & -1.32 & 0.16 & 76.6 \\
Valtournanche & -0.06 & 0.08 & -0.17 & 4.1 \\
\hline
\end{tabular}

$8,1479-1516,2014$

Glacier dynamics in the Western Italian Alps

D. Peano et al.

Title Page

Abstract

Conclusions

Tables

14

4

Back
Introduction

References

Figures

D

$>$

Close

Full Screen / Esc

Printer-friendly Version

Interactive Discussion 


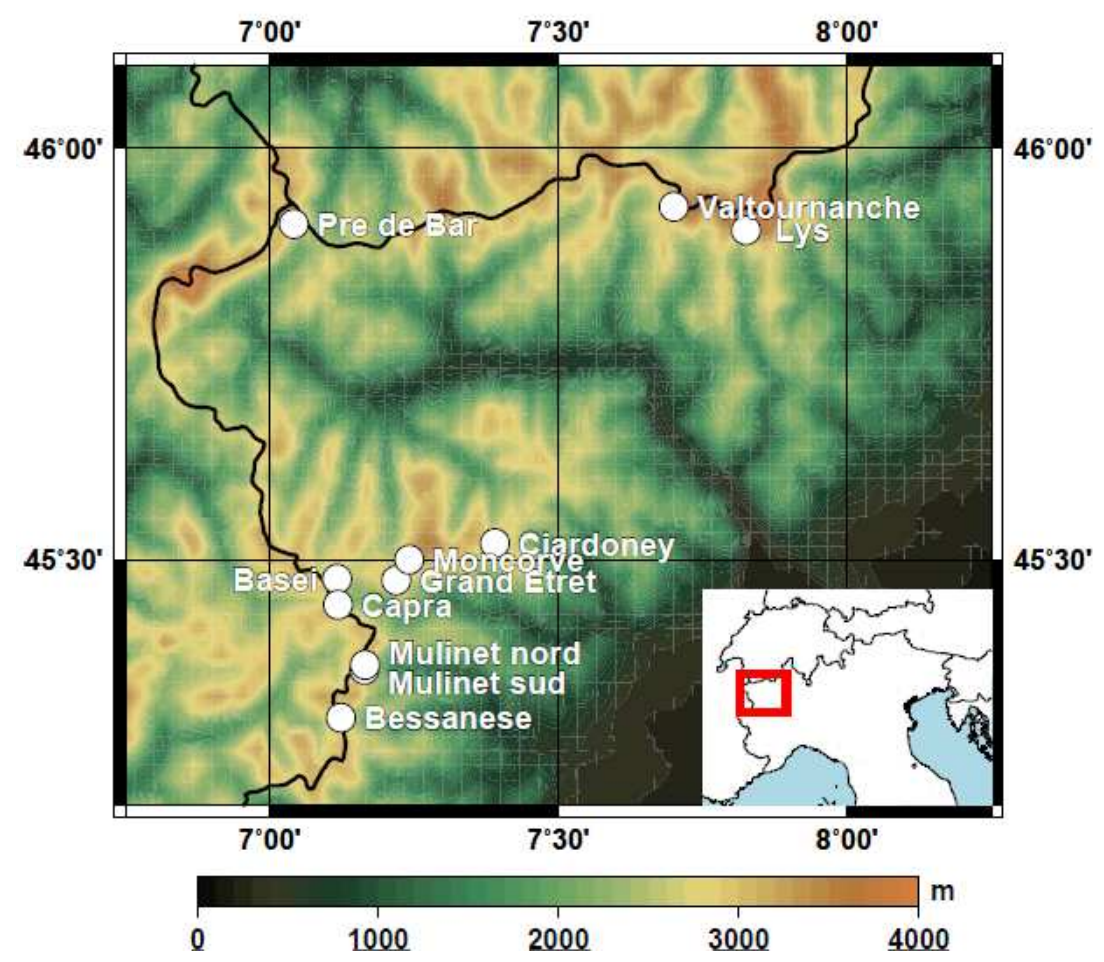

\section{TCD}

8, 1479-1516, 2014

Glacier dynamics in the Western Italian Alps
D. Peano et al.

Title Page

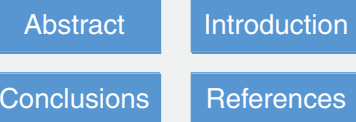

Tables

Figures

14

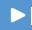

4

Back

Close

Full Screen / Esc

Printer-friendly Version

Interactive Discussion 


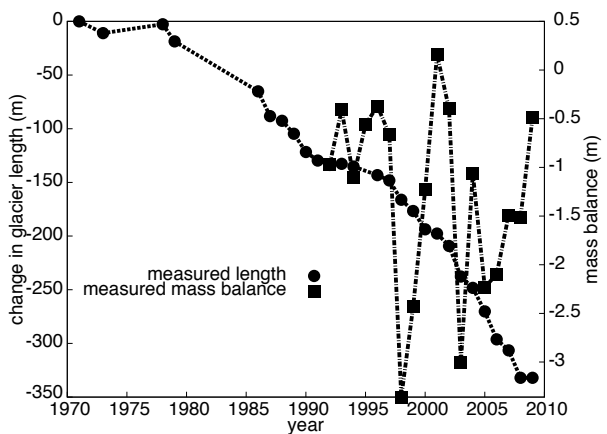

a)

Fig. 2. (a) Cumulative length change of the Ciardoney Glacier in the period 1971-2009 (circles), and measured mass balance in the period 1992-2009 (squares), data from SMI. (b) Cumulative length change of the Grand Etrèt Glacier in the period 1997-2008 (circles), and measured mass balance in the period 2000-2009 (squares), data from GPNP. Circles and squares indicate years with measured data; dotted and dashed lines have only the purpose to guide the eye.
TCD

$8,1479-1516,2014$

Glacier dynamics in the Western Italian

Alps

D. Peano et al.

Title Page

Abstract

Introduction

Conclusions

References

Tables

Figures

14

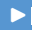

4

Back

Close

Full Screen / Esc

Printer-friendly Version

Interactive Discussion 


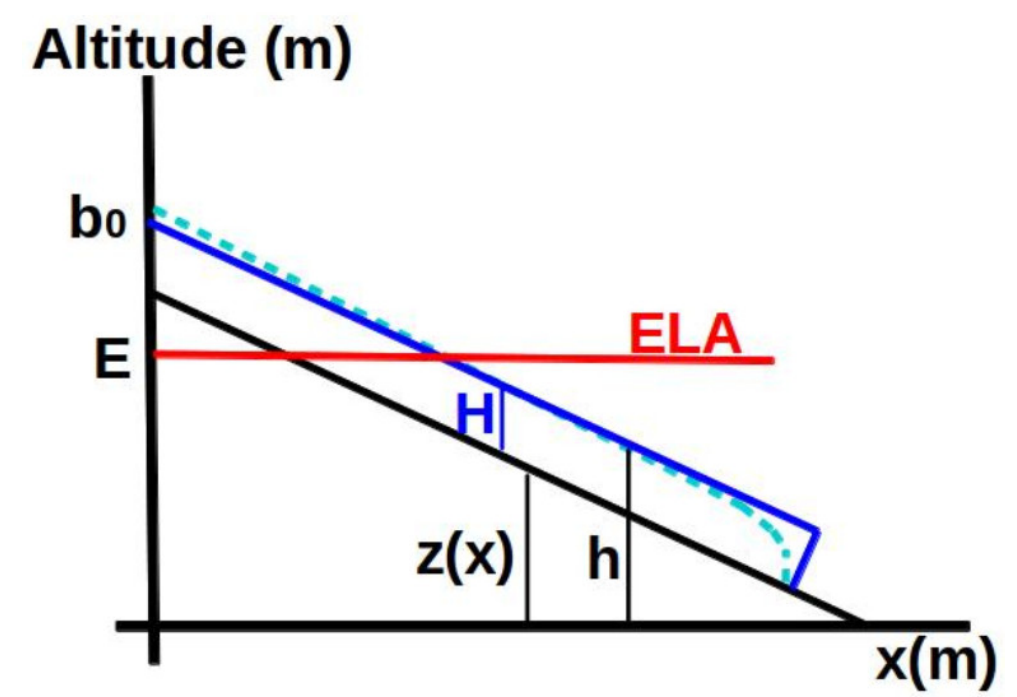

Fig. 3. The simple glacier geometry considered in the minimal model. $E$ represents the equilibrium line altitude, $b_{0}$ is the glacier head altitude, $H$ represents the ice thickness, $z(x)$ is the bed altitude and $h=z(x)+H$. The dark blue line represents the geometry used here, while the light blue one represent the perfect plasticity shape used to obtain Eq. (1).

\section{TCD}

8, 1479-1516, 2014

Glacier dynamics in the Western Italian

Alps

D. Peano et al.

Title Page

Abstract

Introduction

Conclusions

References

Tables

Figures

14

$>1$

4

Back

Close 


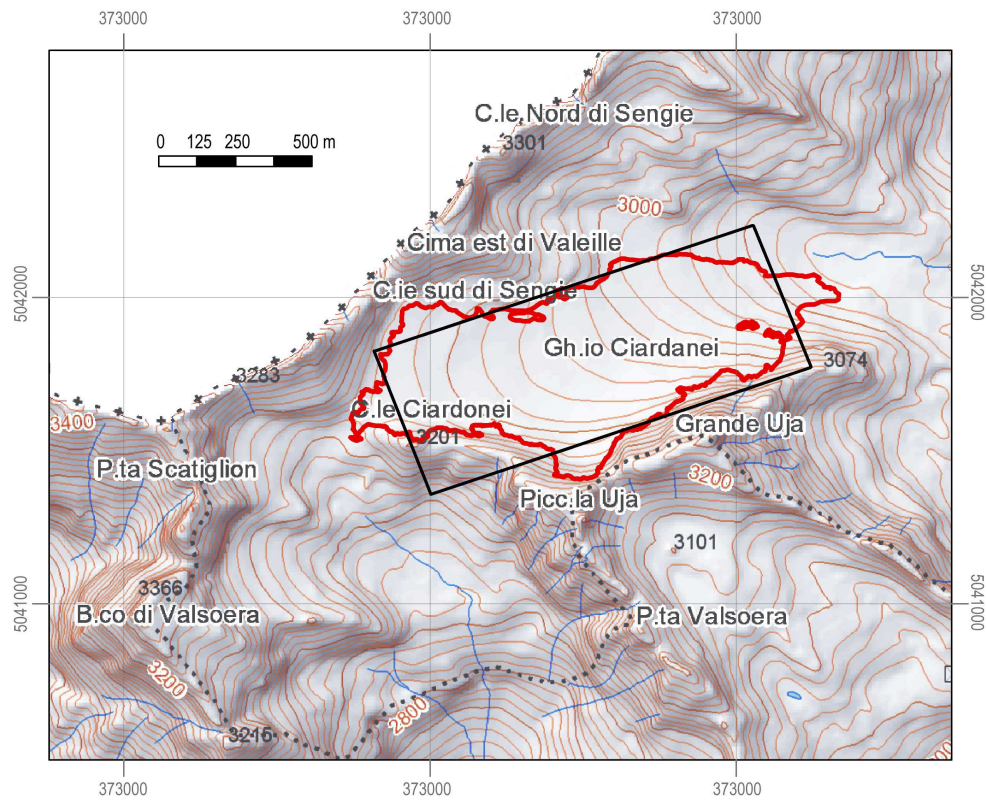

Fig. 4. The Ciardoney Glacier and its representation in the minimal model. The glacier contour is outlined by the red line. The black box represents the simplified glacier geometry used in the model. Map based on the digital topographic map (1:50000) of the Regional Agency for Environmental Protection of Piedmont (ARPA Piemonte), 2011. Graphic by S. Lucchesi.

\section{TCD}

$8,1479-1516,2014$

Glacier dynamics in the Western Italian

Alps

D. Peano et al.

Title Page

Abstract

Introduction

Conclusions

References

Tables

Figures

14

$\rightarrow 1$

Back

Close

Printer-friendly Version

Interactive Discussion 


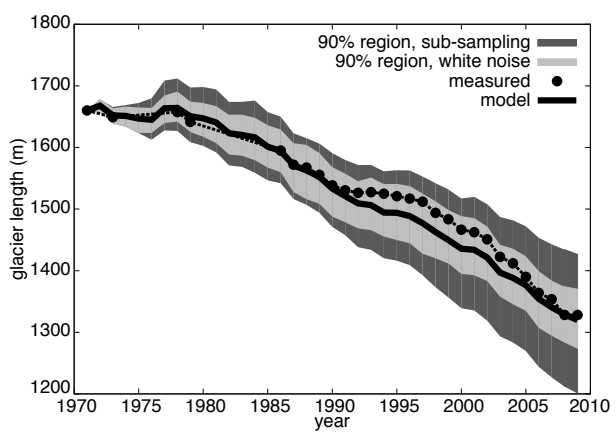

a)

Fig. 5. Application of the model presented in Sect. 2 to the Ciardoney glacier (a) and to the Grand Etrèt glacier (b). Geometrical model parameters are in Table 1. Equation (5) gives the relation between climate variations and surface mass balance values. Circles indicate years with measured length variation while the straight black line represents the model result. The dark gray area is the $90 \%$ confidence region obtained with the "sub-sampling" method, while the light gray area is obtained with the "white noise" method.

\section{TCD}

$8,1479-1516,2014$

Glacier dynamics in the Western Italian

Alps

D. Peano et al.

Title Page

Abstract

Introduction

Conclusions

References

Tables

Figures

14

D

4

Back

Close

Full Screen / Esc

Printer-friendly Version

Interactive Discussion 
a)

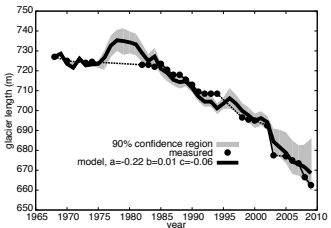

b)
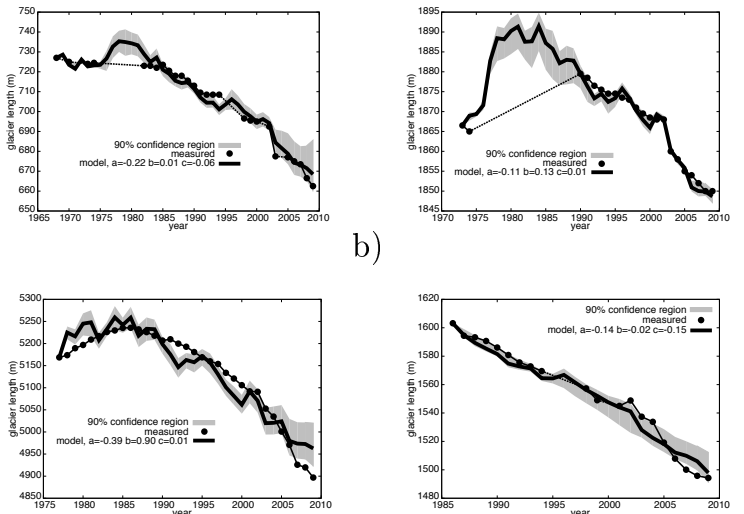

d)

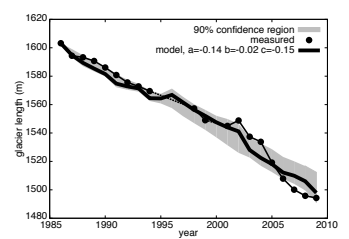

e)

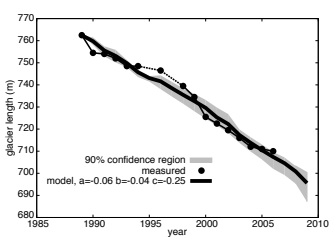

g)

h)

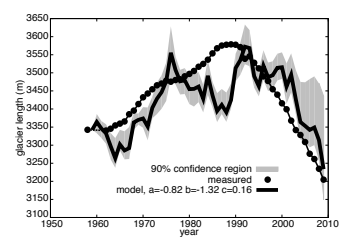

i)

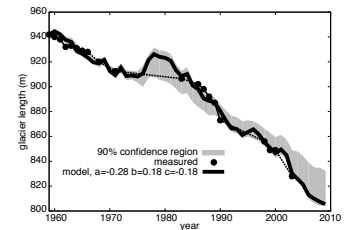

c)

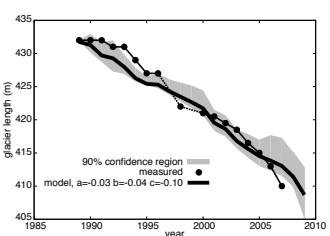

f)

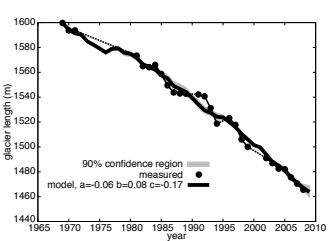

\section{TCD}

8, 1479-1516, 2014

Glacier dynamics in the Western Italian

Alps

D. Peano et al.

\section{Title Page}

Abstract

Introduction

Conclusions

References

Tables

Figures

14

$>1$

4

Back

Close

\section{Full Screen / Esc}

Printer-friendly Version

Interactive Discussion 
a)

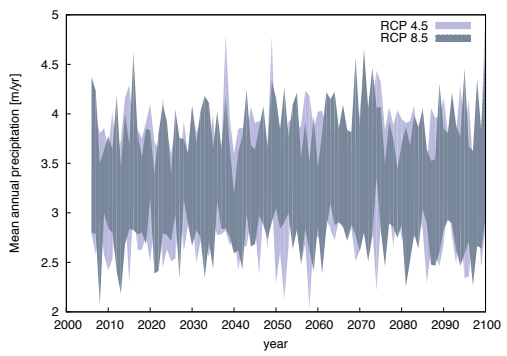

b)

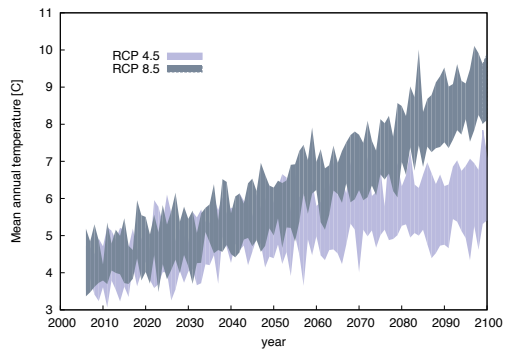

Fig. 7. Precipitation (a) and Temperature (b) variations estimated from an ensemble of ECEarth realizations in the RCP 4.5 (7 monthly cases) and RCP 8.5 (8 monthly cases) future scenarios, for the GCM grid point containing most of the considered glaciers.

\section{TCD}

$8,1479-1516,2014$

Glacier dynamics in the Western Italian

Alps

D. Peano et al.

\section{Title Page}

Abstract

Introduction

Conclusions

References

Tables

Figures

14

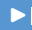

4

Back

Close

Full Screen / Esc

Printer-friendly Version

Interactive Discussion 
a)

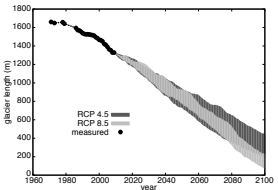

b)
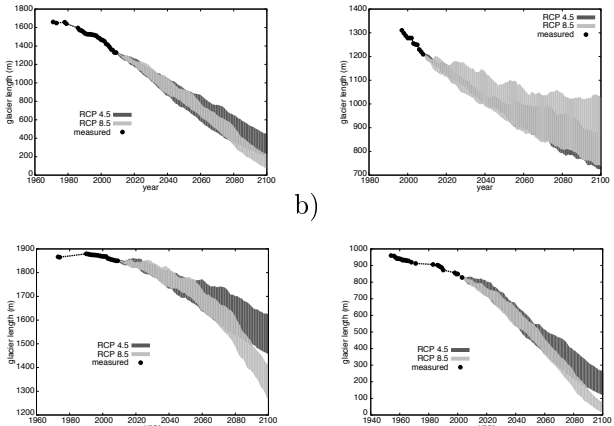

d)

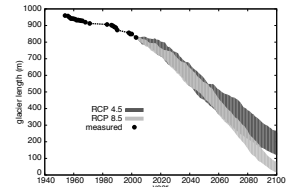

e)

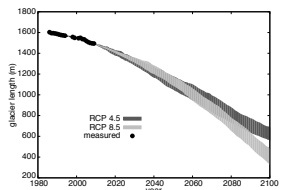

g)

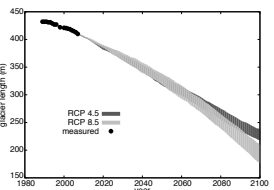

h)

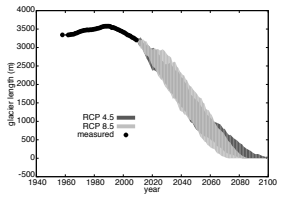

j)

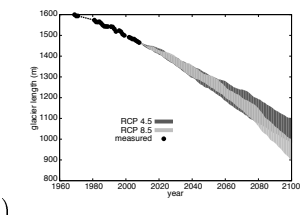

c)
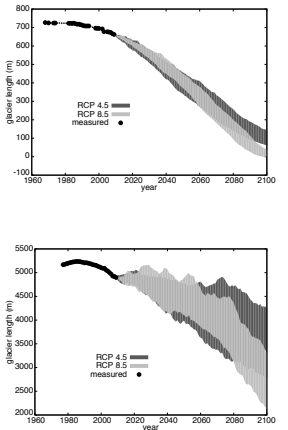

f)

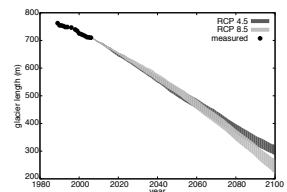

i)

8, 1479-1516, 2014

Glacier dynamics in the Western Italian

Alps

D. Peano et al.

\section{Title Page}

Abstract

Introduction

Conclusions

References

Tables

Figures

14

$>1$

4

Back

Close

Fig. 8. Future evolution obtained using the ensemble values of the future scenario RCP 4.5, and the ensemble values of the future scenario RCP 8.5. Circles represent the measured values of glacier length. (a) Ciardoney Glacier; (b) Grand Etrèt Glacier; (c) Basei Glacier; (d) Bessanese Glacier; (e) Capra Glacier; (f) Lys Glacier; (g) Moncorvè Glacier; (h) Mulinet Nord Glacier; (i) Mulinet Sud Glacier; (j) Prè de Bar Glacier; (k) Valtournanche Glacier. The gray bands indicate the range in lengths obtained from the different ensemble members. Notice that the spreads of the two scenarios should not be compared directly since they are based on a different number of ensemble members.

Full Screen / Esc

Printer-friendly Version

Interactive Discussion 